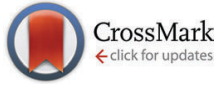

Cite this: J. Mater. Chem. C, 2015 3, 3592

\title{
Near infrared photoluminescence of the univalent bismuth impurity center in leucite and pollucite crystal hosts
}

\author{
A. N. Romanov, ${ }^{\star a}$ A. A. Veber, ${ }^{b}$ D. N. Vtyurina, ${ }^{a}$ Z. T. Fattakhova, ${ }^{a}$ E. V. Haula, ${ }^{a}$ \\ D. P. Shashkin, ${ }^{a}$ V. B. Sulimov, ${ }^{C}$ V. B. Tsvetkov ${ }^{d}$ and V. N. Korchak ${ }^{a}$
}

\begin{abstract}
The bismuth doped aluminosilicate phases leucite $\left(\mathrm{KAISi}_{2} \mathrm{O}_{6}\right)$, gallium leucite $\left(\mathrm{KGaSi}_{2} \mathrm{O}_{6}\right)$ and pollucite $\left(\mathrm{CsAlSi}_{2} \mathrm{O}_{6}\right)$ display broadband NIR photoluminescence. The active center, responsible for this luminescence, is the $\mathrm{Bi}^{+}$monocation, which substitutes for the large alkali metal cations. The Al,Si-disorder in the aluminosilicate framework of studied crystal phases results in the heterogeneity of $\mathrm{Bi}^{+}$luminescent center population, which manifests itself in the characteristic dependency of the luminescence spectrum shape on the excitation wavelength. The relation of NIR emission in $\mathrm{Bi}^{+}$-doped leucite and pollucite phases to the luminescent properties of bismuth-doped glasses is also discussed.
\end{abstract}

Received 14th November 2014,
Accepted 8th February 2015

DOI: $10.1039 / c 4 t c 02606 c$

www.rsc.org/MaterialsC to the net NIR photoluminescence in Bi-doped $\mathrm{SiO}_{2}$ and $\mathrm{GeO}_{2}$-based glasses. ${ }^{37,38}$ To understand the origin of NIR photoluminescence in Bi-containing silicate and germanate glasses, the investigation of model $\mathrm{SiO}_{2}$ or $\mathrm{GeO}_{2}$-based crystals doped with bismuth is highly desirable, since crystal hosts offer a more restrictive and structured environment for the possible bismuth-containing luminescent species. This aspect can diminish the diversity of possible luminescent centers, simplifying the interpretation of photoluminescence spectra. Sun et al. studied the incorporation of NIRluminescent subvalent bismuth centers into the zeolite $\mathrm{Y}$ cages. ${ }^{11-13}$ They have postulated the existence of several NIR emitters $\left(\mathrm{Bi}^{+}\right.$and its oligomeres $\mathrm{Bi}_{2}{ }^{2+}, \mathrm{Bi}_{3}{ }^{3+}$, and $\left.\mathrm{Bi}_{4}{ }^{4+}\right)$ in this system, since the cages of zeolite $\mathrm{Y}$ permit the insertion of large bismuth polycations. Probably, the more restrictive crystalline hosts are desirable to isolate the individual Bi-containing emissive centers and explore their optical properties.

Here we set a goal to prepare the NIR-luminescent bismuthdoped aluminosilicate crystals, where the $\mathrm{Bi}^{+}$monocation can be the solely emissive center. Investigation of such crystals can elucidate greatly the possible contribution of $\mathrm{Bi}^{+}$species to the complex NIR luminescence of bismuth-doped aluminosilicate glasses. Also, these materials can be the perspective for photonics on its own, since, in contrast to the glasses, they contain only one well defined NIR optical center. Taking into account that the $\mathrm{Bi}^{+}$monocation can isomorphically substitute for the large alkali ions $\mathrm{K}^{+}$and $\mathrm{Cs}^{+}$we explore here the preparation and NIR luminescence of $\mathrm{Bi}^{+}$-substituted $\mathrm{KAlSi}_{2} \mathrm{O}_{6}, \mathrm{KGaSi}_{2} \mathrm{O}_{6}$ leucites and $\mathrm{CsAlSi}_{2} \mathrm{O}_{6}$ pollucite polycrystalline materials. 


\section{Materials and methods}

All the glasses and crystalline specimens were produced in Nabertherm HTCT 01/16 and RHTC 80-230/15 furnaces in an air or a nitrogen atmosphere.

Although the $\mathrm{KAlSi}_{2} \mathrm{O}_{6}$ leucite melts congruently at $1686{ }^{\circ} \mathrm{C},{ }^{39}$ the direct preparation of this phase by crystallization from the stoichiometric melt of $\mathrm{K}_{2} \mathrm{CO}_{3}$ (as the source of $\mathrm{K}_{2} \mathrm{O}$ ), $\mathrm{Al}_{2} \mathrm{O}_{3}$ and $\mathrm{SiO}_{2}$ is impeded by the high melting temperature, sufficient melt viscosity and $\mathrm{K}_{2} \mathrm{O}$ volatility at elevated temperatures. That is why we prefer to investigate the crystallization of leucite $\left(\mathrm{KAlSi}_{2} \mathrm{O}_{6}\right)$ diopside $\left(\mathrm{MgCaSi}_{2} \mathrm{O}_{6}\right)$ binary composition. It is known that the leucite-diopside system is of a simple eutectic type with leucite primary crystallization field in the $100-40 \mathrm{~mol} \%$ range. ${ }^{39} \mathrm{We}$ choose the composition 60 leucite-40 diopside molar parts as the basic, because of its reasonable liquidus temperature $\left(\sim 1420{ }^{\circ} \mathrm{C}\right)$, moderate viscosity and easy leucite crystallization. The initial batch was prepared from stoichiometric (relative to 60 leucite-40 diopside molar parts composition) amounts of $\mathrm{K}_{2} \mathrm{CO}_{3}, \mathrm{Al}_{2} \mathrm{O}_{3}, \mathrm{MgO}, \mathrm{CaCO}_{3}$ and $\mathrm{SiO}_{2}$. Five molar parts of $\mathrm{Bi}_{2} \mathrm{O}_{3}$ have been added to this 60 leucite- 40 diopside formulation giving the working composition (60Leu40Dio5Bi thereinafter). The starting compounds were ground in an agate mortar, heated to $1000{ }^{\circ} \mathrm{C}$, ground again and melted at $1550{ }^{\circ} \mathrm{C}$ in air for 15 minutes in a closed alumina crucible. The melt was cooled quickly in air forming the clear amber-colored glass. The crystallization can be induced by heating of the bulk glass material at temperatures from 1400 to $1200{ }^{\circ} \mathrm{C}$ for $20-60$ minutes in a nitrogen atmosphere. The crystallized specimens were usually quenched in water. After the crystallization the specimens became opaque and gray in appearance. The existence of the leucite phase after crystallization was demonstrated by XRD (Fig. 1a). The well shaped dendrite crystals of leucite sometimes formed at the surface of the specimen.

The gallium substituted leucite $\mathrm{KGaSi}_{2} \mathrm{O}_{6}$ is known ${ }^{40}$ and, although its melting point was not reported earlier, we had

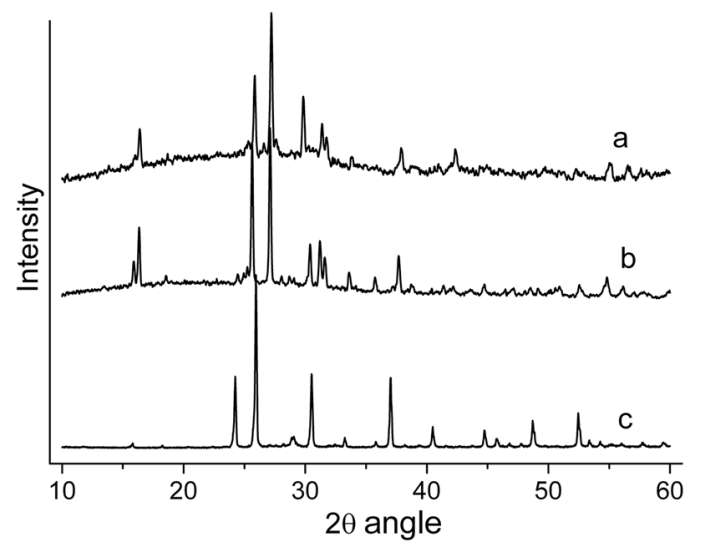

Fig. 1 X-ray diffraction patterns of crystallized 60Leu40Dio5Bi glass (a), crystallized $20 \mathrm{KGaSi}_{2} \mathrm{O}_{6}-1 \mathrm{Bi}_{2} \mathrm{O}_{3}$ glass (b) and the pollucite phase, crystallized from the melt with $7 \mathrm{CsAlSi} \mathrm{O}_{6}-3 \mathrm{~B}_{2} \mathrm{O}_{3}-1.05 \mathrm{Bi}_{2} \mathrm{O}_{3}$ composition and refined from the residual flux by subsequent treatment with $\mathrm{KOH}$ and $\mathrm{HNO}_{3}$ (c). All the noticeable peaks are from leucite $\left(\mathrm{KAISi}_{2} \mathrm{O}_{6}\right)$, gallium leucite $\left(\mathrm{KGaSi}_{2} \mathrm{O}_{6}\right)$ and pollucite $\left(\mathrm{CsAlSi}_{2} \mathrm{O}_{6}\right)$ phases. expected that it will be lower than that of its aluminum counterpart. Indeed, it was possible to prepare rather clear glasses by melting in air at $1550{ }^{\circ} \mathrm{C}$ and quenching the $20 \mathrm{KGaSi}_{2} \mathrm{O}_{6}-1 \mathrm{Bi}_{2} \mathrm{O}_{3}$ composition. The initial batch was composed of the stoichiometric amounts of $\mathrm{K}_{2} \mathrm{CO}_{3}, \mathrm{Ga}_{2} \mathrm{O}_{3}$, $\mathrm{SiO}_{2}$ and $\mathrm{Bi}_{2} \mathrm{O}_{3}$, thoroughly ground in a mortar, calcined at $900{ }^{\circ} \mathrm{C}$ and finally melted for $15-20$ minutes at $1550{ }^{\circ} \mathrm{C}$. The subsequent crystallization of the glasses in nitrogen at $1250{ }^{\circ} \mathrm{C}$ afforded opaque crystalline material with the characteristic leucite XRD diagram (Fig. 1b).

The pollucite phase $\mathrm{CsAlSi}_{2} \mathrm{O}_{6}$ is the most refractory silicate known with a melting point above $1900{ }^{\circ} \mathrm{C} .{ }^{41}$ That is why the bismuth-doped pollucite phases with different $\mathrm{Bi}$ doping concentrations were prepared with the aid of $\mathrm{B}_{2} \mathrm{O}_{3}$ flux. The initial batches with varying bismuth contents $14 \mathrm{CsNO}_{2}-7 \mathrm{Al}_{2} \mathrm{O}_{3}-$ $28 \mathrm{SiO}_{2}-12 \mathrm{H}_{3} \mathrm{BO}_{3}-(0.233 ; 0.7 ; 2.1) \mathrm{Bi}_{2} \mathrm{O}_{3}$ were chosen to give the corresponding $7 \mathrm{CsAlSi}_{2} \mathrm{O}_{6}-3 \mathrm{~B}_{2} \mathrm{O}_{3}-x \mathrm{Bi}_{2} \mathrm{O}_{3}(x=0.117 ; 0.35 ; 1.05)$ final melt compositions when pollucite had formed and all volatiles were evaporated. The constituents were mixed in an agate mortar, calcined at $1000{ }^{\circ} \mathrm{C}$, ground again, melted at $1550{ }^{\circ} \mathrm{C}$ for $15 \mathrm{~min}$ then cooled to $1100{ }^{\circ} \mathrm{C}$ for $4 \mathrm{~min}$. At this temperature the specimens were quenched in water. The clear glass is not formed in this case and the XRD analysis reveals the peaks from pollucite along with a diffuse halo from the remaining glass phase. Since pollucite is more stable toward acid and base attack than leucite it was possible to refine it from the remaining borate glass phase by subsequent treatment of a finely powdered sample with boiling $\mathrm{KOH}$ solution (1 hour) and diluted $\mathrm{HNO}_{3}(5 \mathrm{~min})$ at room temperature. This treatment practically eliminates the intensity of the halo in XRD spectra, leaving clear pollucite diffraction peaks (Fig. 1c) and also (as will be discussed below) eliminates the broad NIR luminescence spectrum, characteristic of the Bi-doped glass phase. To our knowledge, this is the first report of $\mathrm{CsAlSi}_{2} \mathrm{O}_{6}$ pollucite phase crystallization from $\mathrm{B}_{2} \mathrm{O}_{3}$ flux.

The spectra of NIR photoluminescence, luminescence excitation and 2D excitation-emission spectra along with photoluminescence kinetic characteristics were obtained at room temperature as described earlier. ${ }^{17,18,35,36}$

Several CW diode and DPSS lasers with wavelengths of $405 \mathrm{~nm}$, $470 \mathrm{~nm}, 532 \mathrm{~nm}, 635 \mathrm{~nm}, 660 \mathrm{~nm}$ and $690 \mathrm{~nm}$ and 20-200 mW output power were employed to excite the photoluminescence.

XRD characterization was afforded using a DRON-3 X-ray diffractometer.

\section{Results and discussion}

It was described above that bismuth doped compositions 60Leu40Dio5Bi and $20 \mathrm{KGaSi}_{2} \mathrm{O}_{6}-1 \mathrm{Bi}_{2} \mathrm{O}_{3}$ can be obtained in two forms: as quenched clear glass or crystallized specimens, containing $\mathrm{KAlSi}_{2} \mathrm{O}_{6}$ or $\mathrm{KGaSi}_{2} \mathrm{O}_{6}$ leucite phases along with residual glass. The respective quenched glasses exhibit the broad NIR photoluminescence, characteristic for bismuth containing $\mathrm{SiO}_{2}-$ based glasses (Fig. 2 and 3). The shape of the photoluminescence spectra depends on the excitation wavelength, although their 
maxima positions are nearly identical for $\lambda_{\mathrm{ex}}=470 \mathrm{~nm}$ and $\lambda_{\mathrm{ex}}=$ $532 \mathrm{~nm}: \lambda_{\max }=1230 \mathrm{~nm}$ for 60Leu40Dio5Bi glass and $\lambda_{\max }=$ $1247 \mathrm{~nm}$ for $20 \mathrm{KGaSi}_{2} \mathrm{O}_{6}-1 \mathrm{Bi}_{2} \mathrm{O}_{3}$ glass. It is quite accepted now that broadband NIR luminescence in these glasses resulted from several subvalent bismuth species, which are generated from $\mathrm{Bi}^{3+}$ by the thermal reductive dissociation (shown below for $\mathrm{Bi}^{+}$generation):

$$
2 \mathrm{Bi}^{3+}+2 \mathrm{O}^{2-} \rightarrow 2 \mathrm{Bi}^{+}+\mathrm{O}_{2} \uparrow
$$

At sufficiently high temperatures the oxygen partial pressure, generated by process (1), overwhelms the oxygen concentration in the atmosphere, and subvalent bismuth species can be formed by melting of bismuth-containing compositions in the open air.

Upon glass crystallization of both 60Leu40Dio5Bi and $20 \mathrm{KGaSi}_{2} \mathrm{O}_{6}-1 \mathrm{Bi}_{2} \mathrm{O}_{3}$ compositions dramatic changes in NIR luminescence spectra occurred: the luminescence peaks became much sharper (although still rather broad) at every excitation wavelength (Fig. 2 and 3) and blue-shifted relative to the corresponding glasses. The dependency of the photoluminescence spectral shape on the excitation wavelength is more pronounced in these crystallized specimens $\left(\lambda_{\max }=\right.$ $1188 \mathrm{~nm}$ at $\lambda_{\text {ex }}=470 \mathrm{~nm}$ and $\lambda_{\max }=1170 \mathrm{~nm}$ at $\lambda_{\text {ex }}=532 \mathrm{~nm}$ for 60Leu40Dio5Bi glass whereas $\lambda_{\max }=1202 \mathrm{~nm}$ at $\lambda_{\mathrm{ex}}=470 \mathrm{~nm}$ and $\lambda_{\text {max }}=1170 \mathrm{~nm}$ at $\lambda_{\mathrm{ex}}=532 \mathrm{~nm}$ for $20 \mathrm{KGaSi}_{2} \mathrm{O}_{6}-1 \mathrm{Bi}_{2} \mathrm{O}_{3}$ ).

This marked change in the luminescence spectrum upon glass crystallization can be rationalized as the possible interplay between two factors: (i) the initial glass contains many kinds of bismuth NIR luminescent centers, but due to the steric restrictions, only a limited number of such centers (or even one center) can be incorporated into the crystal phase after glass crystallization, resulting in the simplification of the luminescence spectrum and (ii) the spectrum became sharper after the NIR luminescent center transition from the disordered (glass) to ordered (crystal) phase.

The photoluminescence spectra of the crystallized $20 \mathrm{KGa}-$ $\mathrm{Si}_{2} \mathrm{O}_{6}-1 \mathrm{Bi}_{2} \mathrm{O}_{3}$ specimen contains only weak long-wavelength

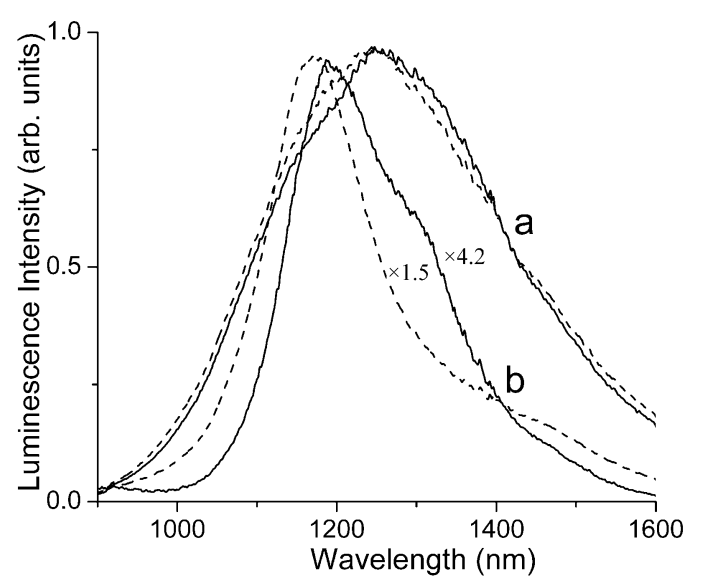

Fig. 2 Photoluminescence spectra of the 60Leu40Dio5Bi glass before (a) and after (b) crystallization. Photoluminescence was excited at $470 \mathrm{~nm}$ (solid line) and $532 \mathrm{~nm}$ (dashed line). The scaling factors for the spectra of crystallized specimens are given relative to the spectra of glass, excited at the same wavelength.

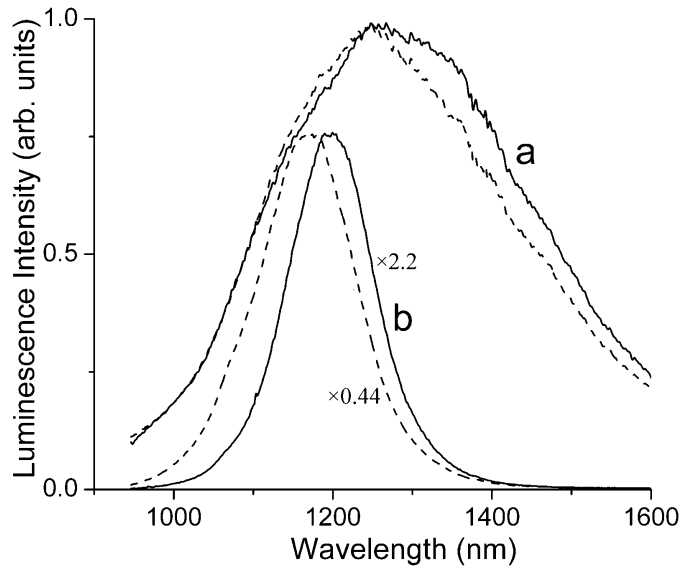

Fig. 3 Photoluminescence spectra of the $20 \mathrm{KGaSi}_{2} \mathrm{O}_{6}-1 \mathrm{Bi}_{2} \mathrm{O}_{3}$ glass before (a) and after (b) crystallization. Photoluminescence was excited at $470 \mathrm{~nm}$ (solid line) and $532 \mathrm{~nm}$ (dashed line). The scaling factors for the spectra of crystallized specimens are given relative to the spectra of glass, excited at the same wavelength.

tails (above $1400 \mathrm{~nm}$ ), whereas in the 60Leu40Dio5Bi specimen these tails are prominent. It is reasonable to consider that these tails originate from the luminescence of the residual glassy phase. Indeed, the crystallized 60Leu40Dio5Bi specimen should contain a large amount of the residual glass, since we did not observe the indications of massive diopside crystallization from this glass (Fig. 1a). So, most of the diopside in this composition should remain glassy.

For the resulting crystalline phases $\mathrm{KAlSi}_{2} \mathrm{O}_{6}$ and $\mathrm{KGaSi}_{2} \mathrm{O}_{6}$ we can assume that due to the large crystal ionic radius of the bismuth ion species, the only cation, which can be substituted by the NIR luminescent bismuth center, is $\mathbf{K}^{+}$. To verify this assumption we synthesize (by a procedure similar to the preparation of 60Leu40Dio5Bi and $20 \mathrm{KGaSi}_{2} \mathrm{O}_{6}-1 \mathrm{Bi}_{2} \mathrm{O}_{3}$ specimens) bismuth doped glasses with pure diopside and spodumene $\left(\mathrm{LiAlSi}_{2} \mathrm{O}_{6}\right)$ compositions, which can be crystallized to the respective crystalline phases. Whereas the diopside and spodumene glasses demonstrated the broadband NIR luminescence, the crystalline diopside and spodumene, resulting from crystallization of these glasses, was completely devoid of NIR photoluminescence or demonstrated only weak luminescence similar to the glassy specimens (probably from the residual glassy phase). This circumstance necessitates to assume that NIR luminescent bismuth centers can substitute only for the large $\mathrm{K}^{+}$cations in $\mathrm{KAlSi}_{2} \mathrm{O}_{6}$ and $\mathrm{KGaSi}_{2} \mathrm{O}_{6}$ aluminosilicates, but not for the relatively small $\mathrm{Li}, \mathrm{Al}$ or $\mathrm{Si}$ ions.

We also succeeded in the preparation of bismuth-doped pollucite from $\mathrm{B}_{2} \mathrm{O}_{3}$-containing flux. As the crystal structures of pollucite and leucite are similar it is no wonder that the NIR luminescence spectra of Bi-doped pollucite are also similar to the Bi-doped leucites (Fig. 4). Also, the Bi-doped pollucite can be prepared in form, sufficiently pure from the remaining non-crystallized glassy phase, which makes it a convenient material for the study of Bi-doped NIR luminescence in aluminosilicate crystals.

One prominent feature of NIR luminescence from Bi-doped leucites and pollucite is the marked dependence of luminescence spectra on the excitation wavelength (Fig. 4, for pollucite 


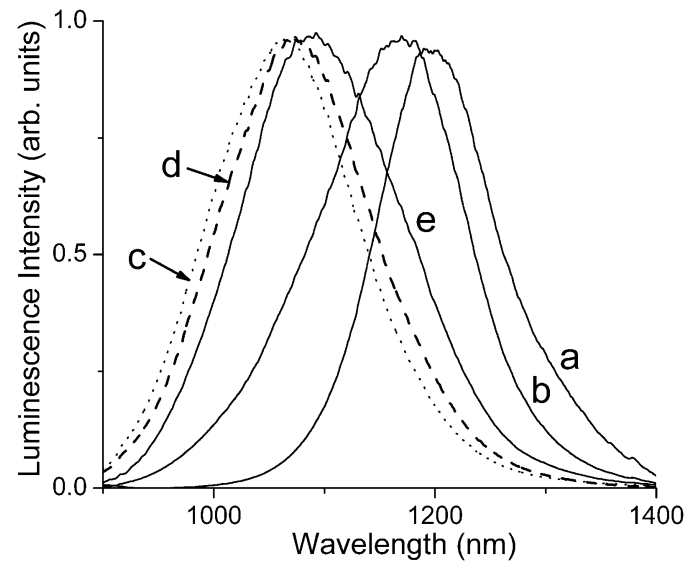

Fig. 4 Photoluminescence spectra of bismuth-doped pollucite, crystallized from the melt with $7 \mathrm{CsAlSi} \mathrm{O}_{6}-3 \mathrm{~B}_{2} \mathrm{O}_{3}-1.05 \mathrm{Bi}_{2} \mathrm{O}_{3}$ composition. The luminescence was excited at $405 \mathrm{~nm}$ (a), $532 \mathrm{~nm}$ (b), $635 \mathrm{~nm}$ (c), $660 \mathrm{~nm}$ (d) and $690 \mathrm{~nm}(\mathrm{e})$.

$\lambda_{\text {max }}=1196 \mathrm{~nm}$ at $\lambda_{\mathrm{ex}}=405 \mathrm{~nm}, \lambda_{\text {max }}=1170 \mathrm{~nm}$ at $\lambda_{\mathrm{ex}}=532 \mathrm{~nm}$, $\lambda_{\text {max }}=1066 \mathrm{~nm}$ at $\lambda_{\mathrm{ex}}=635 \mathrm{~nm}, \lambda_{\text {max }}=1074 \mathrm{~nm}$ at $\lambda_{\mathrm{ex}}=660 \mathrm{~nm}$ and $\lambda_{\text {max }}=1090 \mathrm{~nm}$ at $\lambda_{\text {ex }}=690 \mathrm{~nm}$ ). This dependence implies that several different bismuth-containing luminescent centers are present in the studied aluminosilicate phases. To elucidate the nature of these centers we had prepared the pollucite phases with different amounts of bismuth oxide in the starting mixtures. We found that the increased proportion of bismuth oxide in the batch intensifies the NIR luminescence of the prepared pollucite phase. In fact, the intensities of photoluminescence from the three pollucite specimens prepared with the aid of fluxes with different bismuth contents relate as $1: 2.2: 7.4$ (with excitation at $532 \mathrm{~nm}$ ). This corresponds roughly to the ratio of the bismuth content $(1: 3: 9)$ in the starting mixture - the deviation can be resulted from bismuth evaporation from the flux. This fact signifies that the increased amount of bismuth in the batch leads to the pollucite specimens, containing more bismuth luminescent centers. It is interesting that the overall shape of the luminescence spectra (measured at different excitation wavelengths) is independent of the concentration of luminescent centers in pollucite. So, the photoluminescence spectra, excited at a specified wavelength for specimens with different amounts of $\mathrm{Bi}_{2} \mathrm{O}_{3}$ in the initial batch, can be perfectly superimposed upon one another (Fig. 5). This is in sharp contrast with the properties of Bi-related NIR luminescence from $\mathrm{SiO}_{2}$-based glasses, where the variation of $\mathrm{Bi}_{2} \mathrm{O}_{3}$ concentration markedly affects the shape of the luminescence spectrum. ${ }^{42-44}$

Independence of luminescence spectral shape from bismuth concentration in the melt (represented by $\mathrm{Bi}^{3+}$ and also by subvalent Bi species) signifies that although the prepared pollucite phases contain several Bi-containing luminescent centers, which are all contribute to the net luminescence spectrum, their relative proportions are independent of their concentrations and also of the concentration of $\mathrm{Bi}^{3+}$ as the prevalent bismuth oxidation state in the melt. This independency means that unlike the Bi-doped glasses, multiple luminescent centers in Bi-doped pollucite should have similar oxidation states and a similar number of bismuth atoms.
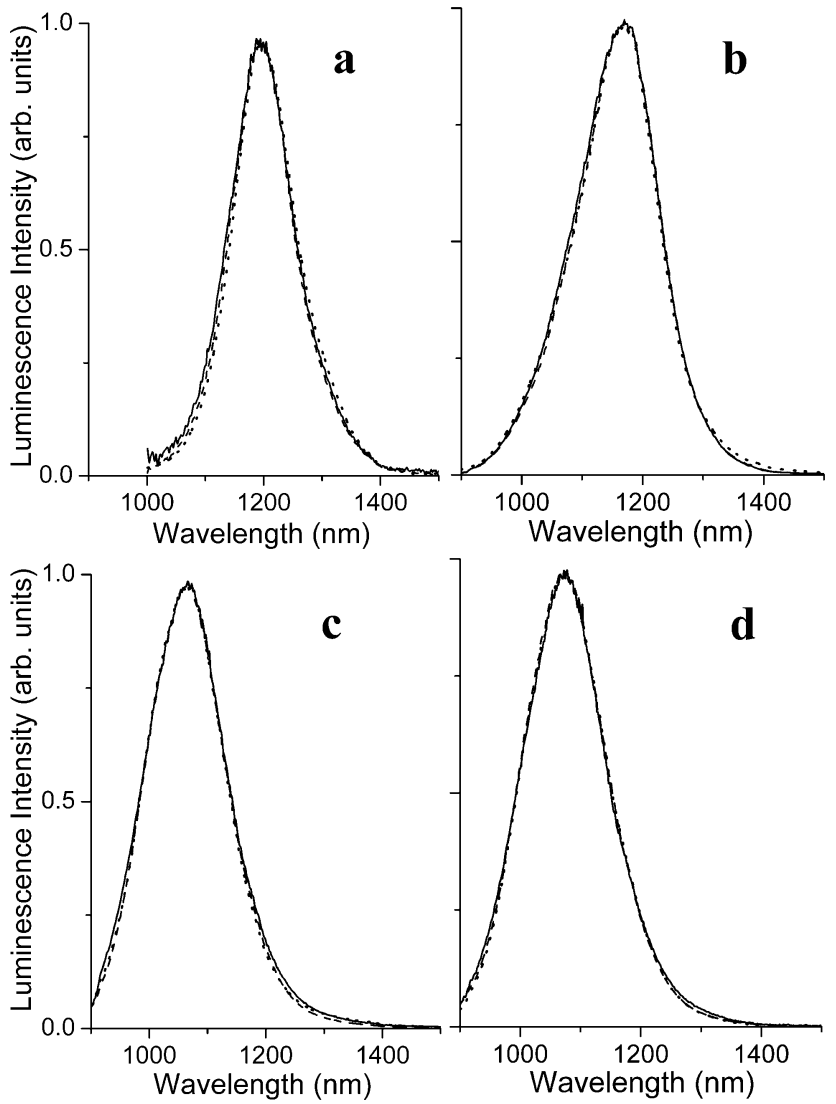

Fig. 5 Photoluminescence spectra comparison for the bismuth-doped pollucite samples, crystallized from the melts with $7 \mathrm{CsAlSi} \mathrm{O}_{6}-3 \mathrm{~B}_{2} \mathrm{O}_{3}-$ $x \mathrm{Bi}_{2} \mathrm{O}_{3}$ compositions, containing different bismuth oxide amounts (for the solid line $x=0.117$; for the dashed line $x=0.35$; and for the dotted line $x=1.05$ ). The luminescence was excited at $405 \mathrm{~nm}$ (a), $532 \mathrm{~nm}$ (b), $635 \mathrm{~nm}$ (c), and $660 \mathrm{~nm}$ (d). The intensity was scaled to superimpose the spectra upon one another.

Indeed, if the luminescent centers would have the different oxidation states (for example $+m$ and $+n, m \neq n, m \neq 3, n \neq 3$ ), their relative proportion should be affected by $\mathrm{Bi}^{3+}$ concentration via the equilibrium reaction:

$$
(3-n) /(n-m) \mathrm{Bi}^{m+}+\mathrm{Bi}^{3+} \leftrightarrow(3-m) /(n-m) \mathrm{Bi}^{n+}
$$

Also, if the luminescent centers would have the same oxidation state but different numbers of bismuth atoms (from dimerization or oligomerization reactions) their relative proportions should depend on their concentrations.

The only explanation for the existence of different luminescent centers with the same oxidation state and the same number of bismuth atoms is the influence of different crystal fields, creating subpopulations of luminescent centers which are essentially the same substance from the chemical point of view but situated in different crystal environments. This is in contrast with the existence of many chemically different oligomeric Bi-containing luminescent species, observed by Sun et al. in zeolite $\mathrm{Y}^{11-13}$ The reason, why we had observed only one chemically unique luminescent Bi center is that the pollucite structure contains significantly smaller cages in 
the aluminosilicate framework than zeolite Y. These small cages do not have enough space to accommodate the different oligomeric subvalent bismuth species. So, the only monoatomic bismuth cautions can be the source of observed NIR luminescence. Since $\mathrm{Bi}^{3+}$ and $\mathrm{Bi}^{2+}$ cannot emit in NIR and it was shown that the $\mathrm{Bi}^{+}$ monocation is the NIR emitter in chloride crystals it is reasonable to postulate that the $\mathrm{Bi}^{+}$center is also the source of NIR photoluminescence in Bi-doped pollucite. Recently, we had estimated the crystal ionic radius of $\mathrm{Bi}^{+}$and demonstrated that the isomorphic substitution of $\mathrm{Cs}^{+}$for $\mathrm{Bi}^{+}$is possible, ${ }^{45}$ so $\mathrm{Bi}^{+}$can readily incorporate into the pollucite framework in place of $\mathrm{Cs}^{+}$.

The varying crystal field parameters at the $\mathrm{Bi}^{+}$site, which create the heterogeneity of luminescent center population, can result from the positional disorder of $\mathrm{Al}$ and $\mathrm{Si}$ in the aluminosilicate framework of the pollucite (and also leucite) structure. In pollucite, the $\mathrm{Cs}^{+}$ion is coordinated by 12 oxygen ions which belong to 15 structural $\mathrm{Si}$ or Al tetrahedra. So, there are many possibilities of different random arrangements of $\mathrm{Si}$ and $\mathrm{Al}$ tetrahedra, around the $\mathrm{Bi}^{+}$center, creating the above mentioned heterogeneity of luminescent center population. Also, the off centering of the $\mathrm{Bi}^{+}$position in the cage and possible crystal lattice defects can also contribute to the inhomogeneous broadening of luminescence. The disorder in the $\mathrm{Cs}^{+}$ion environment of synthetic pollucite was observed earlier by Ashbrook et al. ${ }^{46}$

As the characteristics of NIR luminescence from Bi-doped leucites mimic the emission properties of Bi-doped pollucite, we suggest that the model of the $\mathrm{Bi}^{+}$NIR luminescent center, which we deduce for pollucite, can also be applicable for aluminium and gallium leucites, where $\mathrm{Bi}^{+}$isomorphically substitutes for $\mathrm{K}^{+}$. This suggestion is also strengthened by the data on temporal luminescence decay in Bi-doped gallium leucites, measured at different emission wavelengths. Indeed, we have found that NIR luminescence decay was always single-exponential with lifetimes only slightly varying along the emission wavelength range (401-429 $\mu \mathrm{s}$ in seven measurements at wavelengths from 1100 to $1300 \mathrm{~nm}$, Fig. 6). This implies the similar nature of emissive centers for all

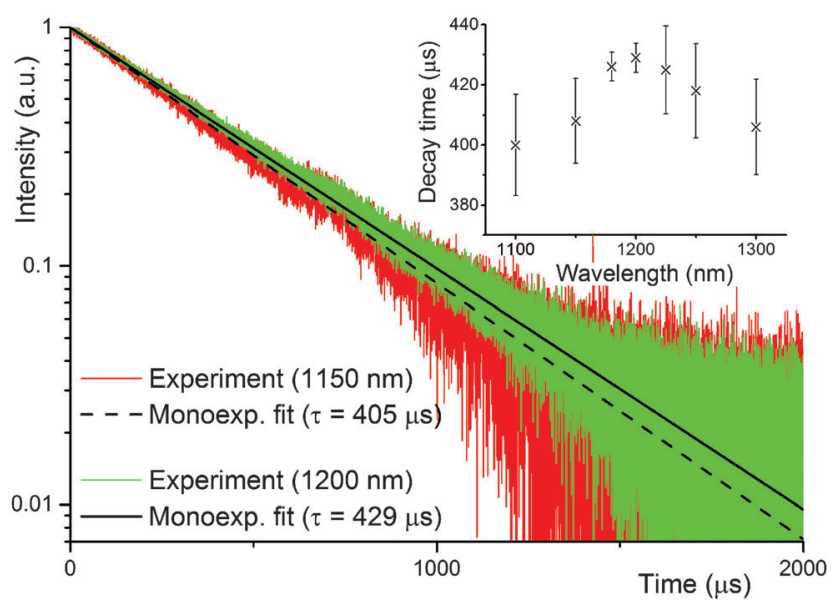

Fig. 6 Photoluminescence decay plots for the bismuth-doped gallium leucite $\left(\mathrm{KGaSi}_{2} \mathrm{O}_{6}\right)$ specimen, registered at 1150 and $1200 \mathrm{~nm}\left(\lambda_{\text {ex }}=\right.$ $532 \mathrm{~nm}$ ). The characteristic decay times, measured at seven different wavelengths, are shown in the inset. observed NIR luminescence spectral diapasons. Also, the characteristic decay time of NIR luminescence is similar to the other crystal phases, ${ }^{18,35}$ doped with $\mathrm{Bi}^{+}$.

Returning to the heterogeneity of $\mathrm{Bi}^{+}$population due to the different crystal environments we can suggest the simple qualitative picture, based on the empirical crystal field model of Davis et $a{ }^{47} \mathrm{Bi}^{+}$monocations in free space exist in the nondegenerate ${ }^{3} \mathrm{P}_{0}$ ground state, the triply degenerate lowest excited ${ }^{3} \mathrm{P}_{1}$ level and then the quintuple degenerate ${ }^{3} \mathrm{P}_{2}$ level. The crystal field of low symmetry in the disordered pollucite lattice splits all the degenerate levels and the lowest energy component from the ${ }^{3} \mathrm{P}_{1}$ manifold forms the level, from which the main radiative transition to the ground state had occurred, causing NIR luminescence. Due to the disordered crystal lattice, the $\mathrm{Bi}^{+}$population is heterogeneous - situated in different crystal environments with varying crystal field strengths. The energy gap between the lowest excited level and the ground state became narrow in the relatively strong-field environment due to increased ${ }^{3} \mathrm{P}_{0}$ split (see Fig. 7). So, the red-shifted portions in the NIR luminescence spectrum are emitted from relatively strong-field luminescent centers. Optical excitation of NIR luminescence is performed via absorbance at transition ${ }^{3} \mathrm{P}_{0} \rightarrow{ }^{3} \mathrm{P}_{2}$ to the components of the split ${ }^{3} \mathrm{P}_{2}$ level with subsequent internal conversion to the luminescent level in ${ }^{3} \mathrm{P}_{1}$ manifold. If we scan the excitation wavelength from blue to the red, decreasing the maximal available energy of the photoexcited state, we firstly change the selection of excited luminescent centers from strong to weak-field, obtaining the luminescence with progressively decreased wavelengths of maxima (Fig. 7). Then, after passing the excitation wavelength, corresponding to the unperturbed ${ }^{3} \mathrm{P}_{0} \rightarrow{ }^{3} \mathrm{P}_{2}$ transition (at zero field), the continued red shift in excitation will produce the opposite effect of selecting relatively more strong-field luminescent centers and the wavelength of luminescence maximum begins to increase with the increase of excitation wavelength. This tendency can be seen in Fig. 4. In this manner, the $2 \mathrm{D}$ excitation-emission spectra of NIR

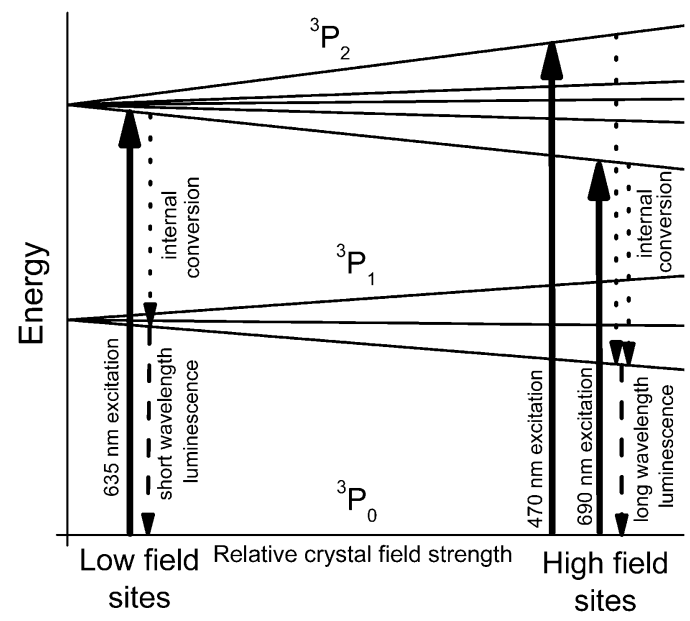

Fig. 7 The influence of the different crystal field strength on the position of the $\mathrm{Bi}^{+}$low excited states and NIR photoluminescence wavelengths in the disordered media. 


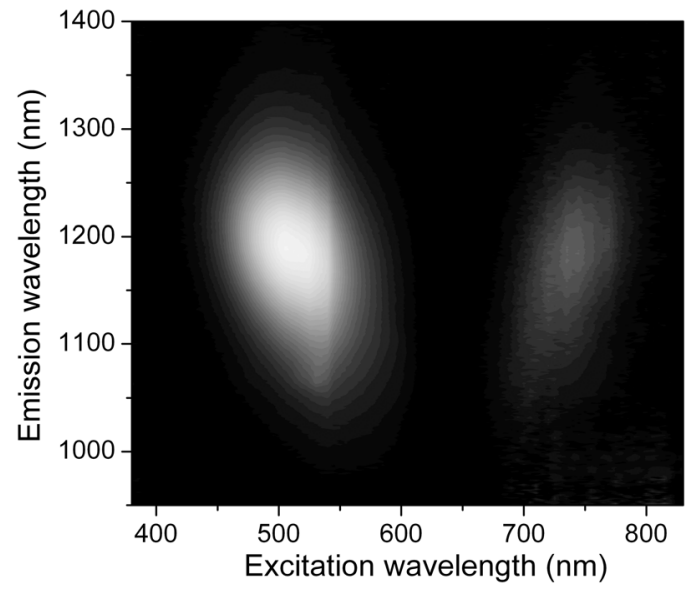

Fig. 8 The dependence of the NIR photoluminescence intensity on the excitation wavelength for the bismuth-doped gallium leucite $\left(\mathrm{KGaSi}_{2} \mathrm{O}_{6}\right)$ specimen. The white color means brighter emission.

luminescence can be viewed as the plots of available excitation energy $v s$. relative crystal field strength, proportional to the emission wavelength. The intensity shown in these spectra illustrates the distribution of luminescent centers $v s$. crystal field strength of its environment. The simple qualitative model explained above should manifest itself in 2D excitationemission spectra as the existence of two branches with opposite dependence of the emission maxima wavelength on excitation one. These two branches intersect each other at the excitation wavelength, corresponding to ${ }^{3} \mathrm{P}_{0} \rightarrow{ }^{3} \mathrm{P}_{2}$ optical transition in the $\mathrm{Bi}^{+}$luminescent center at the zero crystal field. As the population of such weakest-field centers in the specimens is negligible, the intensity of branches nearly vanished at the intersect point, and it can be found only by extrapolation. Such a characteristic 2D excitation-emission plot for the Bi-doped gallium leucite specimen is shown in Fig. 8. The similar 2D plots are also obtained for different Bi-containing NIR luminescent materials, for example, aluminosilicate glasses at a very low Bi-doping level. ${ }^{48}$ They also contain the two well-distinguished branches of luminescence signals. This similarity signifies that in aluminosilicate glass at low $\mathrm{Bi}$ doping concentrations the $\mathrm{Bi}^{+}$ monocation also acts as the main NIR luminescent emitter and as the lasing substance. In the leucite and pollucite aluminosilicate phases, the large alkali cations (and also luminescent $\mathrm{Bi}^{+}$) can be considered as the compensators for the negative charge of the aluminosilicate framework, introduced by $\left[\mathrm{AlO}_{4 / 2}\right]^{-}$four-coordinate aluminium units. Keeping in mind the similarity of NIR luminescence parameters for the $\mathrm{Bi}^{+}$-containing aluminosilicate crystals and glasses at a low Bi-doping level, the NIR luminescence emitter in such glasses can also be considered as the interstitial $\mathrm{Bi}^{+}$, which compensates for the negative charge on the nearby tetrahedral aluminium unit $\left[\mathrm{AlO}_{4 / 2}\right]^{-}$in place of neutral $\left[\mathrm{SiO}_{4 / 2}\right]$ in the $\mathrm{SiO}_{2}$ framework. Such a $\left(\left[\mathrm{AlO}_{4 / 2}\right]^{-}, \mathrm{Bi}^{+}\right)$center was already proposed as the possible NIR emitter (around $1170 \mathrm{~nm}$ ) in bismuth doped aluminosilicate glass, ${ }^{49}$ and bismuth/aluminium codoped zeolite derived glass nanoparticles. ${ }^{50}$ The results of the present investigation also confirm this hypothesis.
Probably, other subvalent and also emissive centers can be formed in glasses at high bismuth doping levels (or without aluminium codoping). These emissive centers can be responsible for the luminescence at relatively long wavelengths, which are also present in leucite glasses, but disappear mainly after crystallization. It was observed earlier that simultaneous existence of different emitting centers in Bi-doped optical materials can hamper the possible laser generation on each of these centers. ${ }^{51}$ So, $\mathrm{Bi}^{+}$-containing aluminosilicate crystals can offer good possibility of creating the solid state laser media with well-defined active centers.

\section{Conclusions}

In contrast to the glass media, the aluminosilicate leucite and pollucite crystals offer a restricted environment to possible subvalent luminescent bismuth centers, so only $\mathrm{Bi}^{+}$monocations are observed as NIR emitting centers at different Bi-doping levels. Despite the existence of only one chemically unique luminescent center, the NIR emission spectra are still rather broad due to the heterogeneity of $\mathrm{Bi}^{+}$luminescent centers in the disordered aluminosilicate network of pollucite and leucites.

\section{Acknowledgements}

The reported work was supported by Russian Foundation for Basic Research (RFBR, research project number 13-03-00777).

\section{References}

1 Y. Fujimoto and M. Nakatsuka, Jpn. J. Appl. Phys., 2001, 40, L279.

2 Y. Fujimoto and M. Nakatsuka, Appl. Phys. Lett., 2003, 82, 3325.

3 X. Meng, J. Qiu, M. Peng, D. Chen, Q. Zhao, X. Jiang and C. Zhu, Opt. Express, 2005, 13, 1628.

4 X. Meng, J. Qiu, M. Peng, D. Chen, Q. Zhao, X. Jiang and C. Zhu, Opt. Express, 2005, 13, 1635.

5 A. N. Romanov, E. V. Haula, Z. T. Fattakhova, A. A. Veber, V. B. Tsvetkov, D. M. Zhigunov, V. N. Korchak and V. B. Sulimov, Opt. Mater., 2011, 34, 155.

6 L. Su, J. Yu, P. Zhou, H. Li, L. Zheng, Y. Yang, F. Wu, H. Xia and J. Xu, Opt. Lett., 2009, 34, 2504.

7 J. Ruan, L. Su, J. Qiu, D. Chen and J. Xu, Opt. Express, 2009, 17, 5163.

8 M. Peng, B. Sprenger, M. A. Schmidt, H. G. L. Schwefel and L. Wondraczek, Opt. Express, 2010, 18, 12852.

9 J. Zheng, M. Peng, F. Kang, R. Cao, Z. Ma, G. Dong, J. Qiu and S. Xu, Opt. Express, 2012, 20, 22569.

10 C. Li, Z. Song, J. Qiu, Z. Yang, X. Yu, D. Zhou, Z. Yin, R. Wang, Y. Xu and Y. Cao, J. Lumin., 2012, 132, 1807.

11 H.-T. Sun, Y. Matsushita, Y. Sakka, N. Shirahata, M. Tanaka, Y. Katsuya, H. Gao and K. Kobayashi, J. Am. Chem. Soc., 2012, 134, 2918. 
12 H.-T. Sun, Y. Sakka, N. Shirahata, Y. Matsushita, K. Deguchi and T. Shimizu, J. Phys. Chem. C, 2013, 117, 6399.

13 H.-T. Sun, A. Hosokawa, Y. Miwa, F. Shimaoka, M. Fujii, M. Mizuhata, S. Hayashi and S. Deki, Adv. Mater., 2009, 21, 3694.

14 A. G. Okhrimchuk, L. N. Butvina, E. M. Dianov, N. V. Lichkova, V. N. Zagorodnev and K. N. Boldyrev, Opt. Lett., 2008, 33, 2182.

15 L. Su, H. Zhao, H. Li, L. Zheng, G. Ren, J. Xu, W. RybaRomanowski, R. Lisiecki and P. Solarz, Opt. Lett., 2011, 36, 4551.

16 L. Su, H. Zhao, H. Li, L. Zheng, X. Fan, X. Jiang, H. Tang, G. Ren, J. Xu, W. Ryba-Romanowski, R. Lisiecki and P. Solarz, Opt. Mater. Express, 2012, 2, 757.

17 A. A. Veber, A. N. Romanov, O. V. Usovich, Z. T. Fattakhova, E. V. Haula, V. N. Korchak, L. A. Trusov, P. E. Kazin, V. B. Sulimov and V. B. Tsvetkov, Appl. Phys. B: Lasers Opt., 2012, 108, 733.

18 A. N. Romanov, A. A. Veber, Z. T. Fattakhova, O. V. Usovich, E. V. Haula, L. A. Trusov, P. E. Kazin, V. N. Korchak, V. B. Tsvetkov and V. B. Sulimov, J. Lumin., 2013, 134, 180.

19 V. G. Plotnichenko, V. O. Sokolov, D. V. Philippovskiy, I. S. Lisitsky, M. S. Kouznetsov, K. S. Zaramenskikh and E. M. Dianov, Opt. Lett., 2013, 38, 362.

20 J. Ren, J. Qiu, D. Chen, C. Wang, X. Jiang and C. Zhu, J. Mater. Res., 2007, 22, 1954.

21 X. Meng, J. Qiu, M. Peng, D. Chen, Q. Zhao, X. Jiang and C. Zhu, Opt. Express, 2005, 13, 1628.

22 M. Peng, C. Zollfrank and L. Wondraczek, J. Phys.: Condens. Matter, 2009, 21, 285106.

23 V. O. Sokolov, V. G. Plotnichenko, V. V. Koltashev and E. M. Dianov, J. Phys. D: Appl. Phys., 2009, 42, 095410.

24 M. Peng, J. Qiu, D. Chen, X. Meng and C. Zhu, Opt. Lett., 2005, 30, 2433.

25 H.-T. Sun, J. Zhou and J. Qiu, Prog. Mater. Sci., 2014, 64, $1-72$.

26 A. S. Zlenko, V. M. Mashinsky, L. D. Iskhakova, S. L. Semjonov, V. V. Koltashev, N. M. Karatun and E. M. Dianov, Opt. Express, 2012, 20, 23186.

27 A. N. Romanov, Z. T. Fattakhova, D. M. Zhigunov, V. N. Korchak and V. B. Sulimov, Opt. Mater., 2011, 33, 631.

28 H.-T. Sun, Y. Sakka, M. Fujii, N. Shirahata and H. Gao, Opt. Lett., 2011, 36, 100.

29 H.-T. Sun, Y. Sakka, H. Gao, Y. Miwa, M. Fujii, N. Shirahata, Z. Bai and J.-G. Li, J. Mater. Chem., 2011, 21, 4060.

30 R. Cao, M. Peng, L. Wondraczek and J. Qiu, Opt. Express, 2012, 20, 2562.

31 R. Cao, M. Peng, J. Zheng, J. Qiu and Q. Zhang, Opt. Express, 2012, 20, 18505.
32 H.-T. Sun, B. Xu, T. Yonezawa, Y. Sakka, N. Shirahata, M. Fujii, J. Qiu and H. Gao, Dalton Trans., 2012, 41, 11055.

33 H.-T. Sun, Y. Sakka, N. Shirahata, H. Gao and T. Yonezawa, J. Mater. Chem., 2012, 22, 12837.

34 H.-T. Sun, T. Yonezawa, M. M. Gillett-Kunnath, Y. Sakka, N. Shirahata, S. C. R. Gui, M. Fujii and S. C. Sevov, J. Mater. Chem., 2012, 22, 20175.

35 A. N. Romanov, A. A. Veber, Z. T. Fattakhova, D. N. Vtyurina, M. S. Kouznetsov, K. S. Zaramenskikh, I. S. Lisitsky, V. N. Korchak, V. B. Tsvetkov and V. B. Sulimov, J. Lumin., 2014, 149, 292.

36 A. A. Veber, A. N. Romanov, O. V. Usovich, Z. T. Fattakhova, E. V. Haula, V. N. Korchak, L. A. Trusov, P. E. Kazin, V. B. Sulimov and V. B. Tsvetkov, J. Lumin., 2014, 151, 247.

37 X. Guo, H. Li, L. Su, P. Yu, H. Zhao, Q. Wang, J. Liu and J. Xu, Opt. Mater., 2012, 34, 675.

38 I. Razdobreev, H. El Hamzaoui, V. Yu. Ivanov, E. F. Kustov, B. Capoen and M. Bouazaoui, Opt. Lett., 2010, 35, 1341.

39 N. L. Bowen and J. F. Schairer, Am. J. Sci., 1929, 18, 301.

40 A. T. Durant, K. J. D. MacKenzie and H. Maekawa, Dalton Trans., 2011, 40, 4865.

41 W. Holand and G. H. Beall, Glass-Ceramic Technology, The American Ceramic Society, John Wiley and Sons Inc., Hoboken, New Jersey, 2nd edn, 2012.

42 M. A. Hughes, T. Suzuki and Y. Ohishi, Opt. Mater., 2009, 32, 368.

43 M. A. Hughes, T. Suzuki and Y. Ohishi, J. Non-Cryst. Solids, 2010, 356, 2302.

44 M. Qian, C. Yu, J. Cheng, K. Li and L. Hu, J. Lumin., 2012, 132, 2634.

45 A. N. Romanov, F. V. Grigoriev and V. B. Sulimov, Comput. Theor. Chem., 2013, 1017, 159.

46 S. E. Ashbrook, K. R. Whittle, L. Le Pollès and I. Farnan, J. Am. Ceram. Soc., 2005, 88, 1575.

47 H. L. Davis, N. J. Bjerrum and G. P. Smith, Inorg. Chem., 1967, 6, 1172.

48 S. V. Firstov, V. F. Khopin, I. A. Bufetov, E. G. Firstova, A. N. Guryanov and E. M. Dianov, Opt. Express, 2011, 19, 19551.

49 V. V. Dvoyrin, V. M. Mashinsky, E. M. Dianov, A. A. Umnikov, M. V. Yashkov and A. N. Guryanov, Proc. 31st European Conference on Optics Communication (ECOC), Glasgow, 2005, vol. 4, p. 949.

50 H.-T. Sun, T. Hasegawa, M. Fujii, F. Shimaoka, Z. Bai, M. Mizuhata, S. Hayashi and S. Deki, Opt. Express, 2009, 17, 6239.

51 R. Gumenyuk, K. Golant and O. G. Okhotnikov, Appl. Phys. Lett., 2011, 98, 191108. 